\title{
Technology and Key Strategy of IE4 Permanent Magnet Brushless DC Motor Drive for Electric Vehicle Application
}

\author{
${ }^{1}$ Nitin Subramonium A K, ${ }^{2}$ Prakhyath Shetty, ${ }^{3}$ G Saravanan, ${ }^{4}$ S Vivekanandan \\ ${ }^{1}$ Project Associate Department of Electrical Engineering Indian Institute of Technology Madras Chennai, India \\ ${ }^{2}$ Engineer, UTC, Bangalore, India \\ ${ }^{3,4}$ Assistant Professor, Department of Electrical and Electronics Engg KPR Institute of Engg and Tech, \\ Coimbatore India
}

ABSTRACT: Environmental protection and energy conservations are the main concern of 21st century Asia Pacific developing countries. This concern has compelled to design and develop zero pollution road transportation Electric Vehicles (EVs). The EV system consist of energy storage devices such as battery, fuel cell, ultra-capacitors along with electric propulsion, body of the vehicle and energy management system with the diversified technology of electrical, electronics, mechanical, automotive and chemical engineering. The objective of electric vehicle is to produce commercial viable range, efficient performance, and comfort with safety and reliable operations at cheaper price than its counterpart the Internal Combustion Engine Vehicle (ICEV). The PMBLDC motors are the present choice of automobile industries and researchers because of its high power density, compact size, reliability, with noise free and minimum maintenance requirements. The present state of art Permanent Magnet Brushless DC (PMBLDC) Motor drive for the electric vehicle application is studied / reviewed in this paper.. In addition the study also reveals the advancement of the Power Processing Unit (PPU) which consists of Microelectronics and Controls (Me and C) to produce the super-premium efficiency PMBLDC drive system for EV applications.

Keywords: PMBLDC motor drive; Fuel cell; Power Processing Unit, Microelectronics and control.

\section{INTRODUCTION}

For the Asia Pacific developing countries 21 st century is an environmental protection century. Electric Vehicles were available in the 19th century till about 1918 [1-10]. Since then, because of the development and viable of ICE, the use electric vehicle for transportation was reduced to nil. But, present factors like environmental pollution problems, shortage of petroleum products and its sharp rise in cost along with energy independence has encouraged to reorganize the electric vehicles as an alternative mode of transportation. In the past decades Direct Current (DC) and Alternating Current (AC) variable speed drives were commonly used for electric vehicle applications. But in this 21 st century because of the availability of high quality rare earth permanent magnet materials like samarium cobalt $(\mathrm{Sm}-\mathrm{Co})$ and Neodymium-Iron-Boron (Nd-Fe-B), the development of PMBLDC motor drives has become highly attractive for EV applications. In addition because of the advancement of microelectronics and control systems the PMBLDC drives has become has more reliable and categorized in to IE4 efficiency (super premium efficiency) classification.

\section{GENERAL SURVEY}

Asia pacific environment: The current Asia Pacific environment related to Electric Vehicle (EV) development can be summarized as below [11]:

- Swift trade and industry development

- Plentiful natural resources

- Low-priced labor

- Less industry

- Practical performance requirement

- Less constraints for new infrastructure

- Major electricity comes from relatively clean sources

Hence, EVs also provide additional new transportation system along with replacement of conventional ICE vehicles [12-17]. From environment aspect, EV provide zero emission transportation and from energy point of view it is ecofriendly and efficient because it offers secure, comprehensive and energy balance spectrum. From transportation point of view, EVs provide intelligent transportation system that will improve road utilization and safety. The motor required for Electric scooter applications should be compact, small axial length, less weight with high efficiency. The aerodynamic drag, tractive force of the load, i.e. the road should be overcome by the torque developed by PMBLDC motor propulsion. Higher motor driving current is the major limitation of the PMBLDC motor. 


\section{International Energy (IE) Standard:}

The increase in electric motor efficiency contributes to the worldwide energy savings. To make this possible International Electrotechnical Commission (IEC) has made International Energy (IE) to develop the standards and performance of the motor drives [18-19]. The main concern of IE standards is efficiency which can be categorized as

- IE 1 (standard efficiency)

- IE 2 (high efficiency)

- IE 3 (premium efficiency)

- IE 4 (super premium efficiency)

- IE 5 (ultra-premium efficiency)

Currently this classification run from IE 1 to IE 4, but at present stage IE 3 is made mandatory in some countries so that performance can be increased. IE 4 standard is still not legally applied, but the regulation and specification are defined. The manufacturers use IE 4 as the readiness for implementation. The IE standards are already designed for the motor ranging from $0.75 \mathrm{~kW}$ to $375 \mathrm{~kW}$, within which the motor of $7.5 \mathrm{~kW}$ to $375 \mathrm{~kW}$ mandatory rule for some application is made to follow from 2015 and for low power from $0.75 \mathrm{~kW}$ is 2017 . With the up gradation to IE 4 standards efficiency can be brought up for the machines of $120 \mathrm{~W}$ to $500 \mathrm{~kW}$.

Comparison between electric vehicle and conventional vehicle [20]:

TABLE I: Comparison between electric vehicle and conventional vehicle

\begin{tabular}{|l|c|c|}
\hline Feature & Electric vehicle & $\begin{array}{c}\text { IC Engine } \\
\text { vehicle }\end{array}$ \\
\hline Prime mover & Electric motor & IC Engine \\
\hline Powered Source & $\begin{array}{c}\text { Charged battery, } \\
\text { Ultra capacitor } \\
\text { Fuel Cell }\end{array}$ & Diesel, Petrol \\
\hline Self-weight & High & Low \\
\hline $\begin{array}{l}\text { Transmission } \\
\text { system }\end{array}$ & $\begin{array}{c}\text { Both electrical as } \\
\text { well as mechanical }\end{array}$ & Mechanical \\
\hline Braking system & $\begin{array}{c}\text { Regenerative } \\
\text { braking }\end{array}$ & $\begin{array}{c}\text { Friction } \\
\text { braking }\end{array}$ \\
\hline Efficiency & Low & High \\
\hline Eco friendly & Yes & No \\
\hline Initial cost & High & Average \\
\hline Running cost & Low & Very high \\
\hline
\end{tabular}

The IC engine efficiency is low because of heat loss also its cooling system is of intricate. On the other hand electrical machines have higher efficiency than ICE.

\section{CLASSIFICATION OF ELECTRIC VEHICLE}

A. Electric Vehicle

1 Battery operated electric vehicle

2 Battery and ultra-capacitor operated electric vehicle

3 Solar operated electric vehicle

B. Hybrid Electric Vehicle

1 Fuel cell operated electric vehicle

2 Hybrid electric vehicle

\section{VEHICLE ARCHITECTURE}

Electric vehicle is a complicated assembly dealing with various fields like Mechanical, Electrical, Control, Magnetic, Electrochemical, Thermal, Chemical etc [21-24]. The fuel tank of the conventional vehicle is replaced by the battery bank. Power AC mains supply or fuel cell is used charge the batteries. The arrangement is provided to charge these batteries either by regular power chargers or by fast chargers which varies on the type of chargers. The power controller is provided to control the power supply to the motor. To supply the power to auxiliaries and peripheral devices a separate $12 \mathrm{~V}$ battery is provided.

The heart of an electric vehicle is combination of the electric motor, controller and the batteries. The batteries deliver the power to the controller and thus to the motor. The accelerator knob is coupled to a pair of potentiometers (variable resistors) which provides the signal to the controller estimating the power to be delivered for the particular load condition. The controller can deliver zero power (when vehicle is at rest),full power(when accelerator nob is raised to full speed),or any power level in between. The variable power could be delivered by the application of very large thyristers that rapidly turn the batteries voltage on and off [25-29]. The signal from the potentiometers decides the power to be delivered to the electric motor.

\section{Motor Drive:}

Usually the electric motors are used where it is run for long time, constant speed, slightly variable loads etc,. But for electric vehicle application the motor needs to start, stop frequently, periodic acceleration and deceleration which cannot be compared with industrial electric motors. In order to suit the motor for electric vehicle application some of the key features have to be satisfied to operate at good performance and efficiency. The motor for electric vehicle should have high torque for starting and uphill propulsion, higher power density for acceleration and speeding, capacity to bear over load for certain interval of time, reliable, efficient and cost affordable. The speed torque characteristics of the motor decide the 
Nitin Subramonium A K.et.al. Int. Journal of Engineering Research and Application www.ijera.com ISSN : 2248-9622, Vol. 7, Issue 2, ( Part-4) February 2017, pp.25-31

suitability of the motor. Figure I and Figure II shows the speed- torque characteristics of the desired electric vehicle motor [30] and standard electric motor [31].

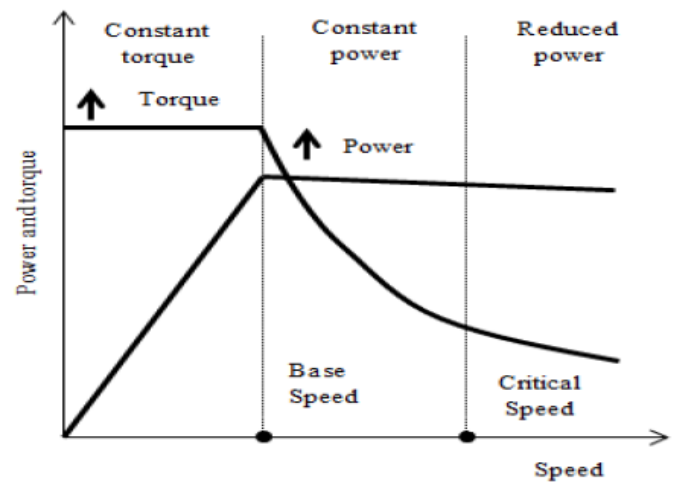

Figure I: Speed- torque characteristics of desired electric vehicle motor

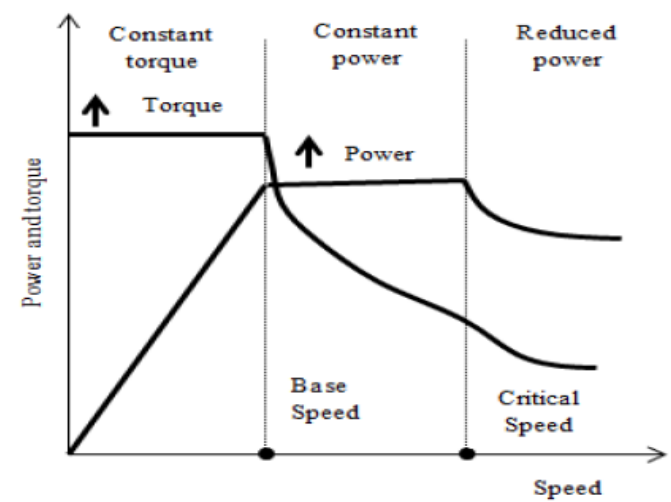

Figure II: Speed- torque characteristics of standard electric motor

TABLE II: Comparison between different types of $\mathrm{DC}$ and $\mathrm{AC}$ machines used for EV applications

\begin{tabular}{|l|l|l|l|}
\hline Features & $\begin{array}{l}\text { BLDC } \\
\text { Motor }\end{array}$ & $\begin{array}{l}\text { Brushed DC } \\
\text { motor }\end{array}$ & $\begin{array}{l}\text { AC } \\
\text { Induction } \\
\text { Motor }\end{array}$ \\
\hline $\begin{array}{l}\text { Speed Vs } \\
\text { Characteri } \\
\text { stics }\end{array}$ & $\begin{array}{l}\text { Linear. } \\
\text { Hence } \\
\text { operation } \\
\text { at all } \\
\text { speeds } \\
\text { with rated } \\
\text { load is } \\
\text { possible. }\end{array}$ & $\begin{array}{l}\text { Moderately } \\
\text { flat. } \\
\text { Approximatel } \\
\text { y linear. } \\
\text { Torque } \\
\text { developed is } \\
\text { decreased at } \\
\text { high speeds } \\
\text { due to friction } \\
\text { of the brushes }\end{array}$ & $\begin{array}{l}\text { Non- } \\
\text { Linear. At } \\
\text { low } \\
\text { speeds } \\
\text { developed } \\
\text { torque is } \\
\text { less. }\end{array}$ \\
\hline $\begin{array}{l}\text { Commutat } \\
\text { ion }\end{array}$ & Electronic & Brushed & $\begin{array}{l}\text { Moderate / } \\
\text { e }\end{array}$ \\
\hline Eating/siz & High & low \\
\hline $\begin{array}{l}\text { Maintenan } \\
\text { ce }\end{array}$ & Less & frequent & fow \\
\hline Speed & high & low & high \\
\hline
\end{tabular}

\begin{tabular}{|l|l|l|l|}
\hline $\begin{array}{l}\text { range } \\
\text { Nlectric } \\
\text { Noise }\end{array}$ & Low & High & moderate \\
\hline control & $\begin{array}{l}\text { Complex } \\
\text { and } \\
\text { expensive }\end{array}$ & $\begin{array}{l}\text { Simple and } \\
\text { inexpensive }\end{array}$ & $\begin{array}{l}\text { Simple } \\
\text { and } \\
\text { inexpensiv } \\
\text { e }\end{array}$ \\
\hline Life & Longer & Short & moderate \\
\hline Slip & No slip & No slip & Present \\
\hline $\begin{array}{l}\text { Starting } \\
\text { Current }\end{array}$ & rated & & $\begin{array}{l}\text { 5-7 times } \\
\text { rated } \\
\text { current }\end{array}$ \\
\hline
\end{tabular}

The DC motors characteristics are suitable for EVs. But its limitations are the commutator and brushes. However the Power Processing Unit (PPU) used for DC motor is economically cheaper than used for three phase induction motor [32-38]. The purpose of commutator and brushes are now implemented by means semiconductor devices. As a result zero maintenance motors were developed which are known as brush less dc motors. Since, these PMBLDC motors are without commutator and brushes their maintenance is very low also there is increase in efficiency and power-to-weight ratio. Hence, present trend is to use PMBLDC motor drive for electric vehicles. The cost of PMBLDC motor drive has two main components, namely motor and the controller. The ease of control of the motor has made the researchers to take up the motor to work at efficiency and cost reduction and commercialize the application of the motor. Due to these features PMBLDC motor drives finds the wide application in low power drives and automotive. PMBLDC motors are well known for less maintenance, long life, low EMI and quiet operation. The output power of these motors produce more output power per frame than other motors.

TABLE III: Required scooter parameters

\begin{tabular}{|l|l|l|l|}
\hline $\begin{array}{l}\text { S1. } \\
\text { No }\end{array}$ & \multicolumn{1}{|c|}{ Parameter } & Values & \multicolumn{1}{|c|}{ Unit } \\
\hline 1 & Total mass of vehicle, people & 200 & $\mathrm{Kg}$ \\
\hline 2 & Maximum acceleration & 0.65 & $\mathrm{~m} / \mathrm{s}^{2}$ \\
\hline 3 & $\begin{array}{l}\text { Coefficient of normal type } \\
\text { rolling resistance }\end{array}$ & 0.013 & \\
\hline 4 & Density of air & 1.23 & $\mathrm{Kg} / \mathrm{m}^{3}$ \\
\hline 5 & Drag coefficient & 0.6 & \\
\hline 6 & Frontal area & 0.8 & $\mathrm{~m}^{3}$ \\
\hline 7 & Angle of slope & 12 & degree \\
\hline
\end{tabular}

These values are necessary to calculate torque, power and speed of the PMBLDC motor drive. The electric motor for this application should be small in size, light weight and higher efficiency. In order to fit the motor into the scooter it should have a short axial length. Sufficient torque has to be generated to overcome the rolling resistance, drag, tractive force against gravitation during locomotion. The other constraints such as the size 
of the motor, size of the tyre, driving current and output power are to be taken into consideration. Hence, the feasibility of PMBLDC motor drive is studied from the technical specifications as mentioned in Table IV

TABLE IV: Technical specification of the motor drive

\begin{tabular}{|l|l|l|l|}
\hline $\begin{array}{r}\text { Sl. } \\
\text { No }\end{array}$ & \multicolumn{1}{|c|}{ Parameter } & Values & \multicolumn{1}{|c|}{ Unit } \\
\hline 1 & Rated voltage & 48 & $\begin{array}{l}\text { Volts } \\
\text { (DC) }\end{array}$ \\
\hline 2 & Rated power & 500 & Watts \\
\hline 3 & Rated torque & 1.27 & $\mathrm{Nm}$ \\
\hline 4 & Rated speed & 3000 & $\mathrm{Rpm}$ \\
\hline 5 & Rated current & 11.4 & Amps \\
\hline 6 & Peak current & 34.2 & Amps \\
\hline 7 & Peak torque & 3.81 & $\mathrm{Nm}$ \\
\hline 8 & Resistance & 0.94 & Ohms \\
\hline 9 & Inductance & 1.19 & $\mathrm{mH}$ \\
\hline 10 & Electrical time constant & 1.26 & $\mathrm{~ms}$ \\
\hline 11 & Mechanical time constant & 4.91 & $\mathrm{~ms}$ \\
\hline 12 & Voltage constant & 10.1 & $\mathrm{v} / \mathrm{krpm}$ \\
\hline 13 & Torque constant & 0.128 & $\mathrm{Nm} / \mathrm{A}$ \\
\hline 14 & Rotor moment of inertia & 0.51 & $\mathrm{Kg} \cdot \mathrm{cm}{ }^{2}$ \\
\hline 15 & Motor length & 130 & $\mathrm{Mm}$ \\
\hline 16 & Motor weight & 1.6 & $\mathrm{Kg}$ \\
\hline
\end{tabular}

\section{Storage Technologies for Electric vehicle:}

\section{A. Batteries in electric vehicle:}

Lead acid battery: The spongy lead acts as negative active material of the battery, lead oxide is the positive active material and dilute sulfuric acid is the electrolyte. For discharging, both materials are transformed into lead sulphate [39-41]. These are sealed batteries which provide maintenance free operation and long-term application is possible.

Lithium-ion battery: The positive electrode is composed of an oxidized cobalt material, the negative is of carbon material and lithium salt in an organic solvent is the electrolyte. These are lighter in weight and good efficiency and energy density. These have good self-discharge rate.

Sodium sulphate battery: These batteries bear very high energy density and wide application for low power drives.

Nickel based battery: The aqueous, room temperature batteries such as nickel iron (Ni-Fi), Nickel Cadmium (Ni- $\mathrm{Cd}$ ) and Nickel-metal hydride (Ni-MH) finds higher advantages due to high peak power and higher energy density. Also these batteries are safe materials and totally sealed for maintenance free operation. Ni-MH batteries eliminates Cadmium from the negative electrode and finally from entire cell. In $\mathrm{Ni}-\mathrm{MH}$ battery positive electrode is made up of nickel hydroxide, negative is made of an alloy of vanadium, titanium, nickel and other metals. Ni-Cd batteries have the greater advantage on the range of operating temperature [42].

\section{B. Fuel Cell:}

The electric vehicle using fuel cell instead of battery is called fuel cell electric vehicle in which electricity to power the wheels of vehicle is supplied by fuel cell. But a battery must be recharged once all the fuel is reacted; a fuel cell is a refillable battery. The fuel cell generates power from the fuel on the anode and oxidant on the cathode and the reaction takes place in the presence of electrolyte. The reactants flows into the cell during the process of generation mean while the products flows out, the generation continues as far as the process is maintained. The major advantage of fuel cell is higher efficiency in conversion, quit operation, fuel flexibility, durability and reliability.

Various combinations of fuel and oxidant is possible, hydrogen is a non-polluting fuel for fuel cell that after reaction it liberates water and it has the highest energy density. Other fuels are hydro-carbons and alcohols and oxidants being chlorine and chlorine oxide. The efficiency of the fuel cell depends on the power drawn, higher the power drawn, lower is the efficiency. Losses occur due to the voltage drop on the internal resistance and the fuel cells have relatively longer response time [43-45]. Also, fuel cells are more expensive than the other batteries.

\section{Flywheel:}

Flywheel is a device that stores and delivers the energy in the mechanical motion due to size and weight problem, the use is being reduced in electrical vehicle application as these require minimal size and weight. Flywheel energy storage takes place when flywheel is accelerated to high speed and rotational energy is maintained. As and when the energy in the flywheel is extracted, the rotational speed reduces as a consequence of principle of conservation of energy. The energy storage in flywheel is directly proportional to its mass and square proportional to velocity from supply and delivers to the load as per the requirement. Sl. No Parameter Values Unit 1 Rated voltage 48 Volts (DC) 2 Rated power 500 Watts 3 Rated torque 1.27 Nm 4 Rated speed 3000 Rpm 5 Rated current 11.4 Amps 6 Peak current 34.2 Amps 7 Peak torque $3.81 \mathrm{Nm} 8$ Resistance 0.94 Ohms 9 Inductance $1.19 \mathrm{mH} 10$ Electrical time constant 
$1.26 \mathrm{~ms} 11$ Mechanical time constant $4.91 \mathrm{~ms} 12$ Voltage constant $10.1 \mathrm{v} / \mathrm{krpm} 13$ Torque constant $0.128 \mathrm{Nm} / \mathrm{A} 14$ Rotor moment of inertia 0.51 Kg.cm2 15 Motor length $130 \mathrm{Mm} 16$ Motor weight $1.6 \mathrm{Kg}$ Due to the advancement in bearing, carbonfiber composite materials, micro-electronics and controls has made the wide application of flywheel [46-48]. As a result of these improvements numerous advantages are added to this category i.e, efficiency, reliability, high speed at lower weight and size, thus made the storage system more suitable for electric vehicular propulsion system. The recent flywheels can store more power and energy when compared to the conventional batteries. These are independent of indepth discharge thus does not alter the life cycle of the system.

\section{Hybrid Energy System:}

The battery and fuel energy systems have high specific energy but less specific power when compared to flywheel. It can be said that apart from energy density, voltage and current characteristics of the different energy storage system are different. Combination of the energy system with proper calculation and placing can improve the performance of the system [49-50]. This condition is called hybrid energy system. The combination depends on the type of vehicle and the required output. With the combination of storage system, both energy density and power density could be enhanced. The application of only system for higher power density like flywheel increases the cost, weight and size but with combination, the problem could be solved. The overall efficiency, reliability, durability can be improved with this storage system and also concern the cost and weight.

\section{COMMERCIAL ASPECTS TO POPULATE THE ELECTRIC VEHICLE IN RURAL AREA:}

There is a lot of scope for battery operated electric and hybrid vehicles in rural areas in Udupi as the people are aware of the crisis of energy and increasing fuel cost. But small mandatory changes in the Government and local authorities will help in reaching the people more affectively on road and upgrade the efficiency to IE 3 standards and further to IE 4. For small rural and urban works people used to travel in two wheelers with two seats, within which $90 \%$ of the riders travel alone with another seat empty. But two wheeler one seat is not so much commercialized as those are used in some industries and in some executive office works. For one person ride the vehicle need not have that higher torque and high speed when compared to two. Thus for these one person ride two wheeler, single seat is more suitable and electric scooter suits the case well. As the commercial vehicles are IC engine powered these have high speed, thus battery operated low speed vehicles are now considered as the alternative for cycles. The main factors of low speed, limited range and high initial cost are main hurdles in popularizing the two wheelers. The replacement to present vehicle to electric vehicle can be effectively achieved by implementation of electric vehicle in the form of three wheelers at the initial stage and then commercialize the two wheelers, thus contribute to the crisis.

Safety: The industries dealing with chemical, explosive, petroleum where there are dangers of fire hazards, battery operated electric vehicles can be utilized for such applications.

Air Pollution: The factories like food products, pharma industries where the process has to be carried in air conditioned premises and gas emissions are not allowed.

Sound Pollution: Holiday resorts, wildlife sanctuaries, hospitals are main systems where people expect peace and calm, battery operated electric vehicles can be used so that there will not be any delay in the transportation.

\section{BENEFITS OF ELECTRIC VEHICLE}

- The battaries for the Electric vehicle will be charged in off-peak hours, this condition helps in ulilizing the base load plant, hence the generated power can be used for the development of renewable energy sources.

- Electric Vehicle works at higher efficiency compared to conventional IC engine vehicle, that hardly it works at $35 \%$ efficiency.

- Reduces air pollution and Global warming problems

- Reduction in the use of depleting fossil fuels.

\section{REFERENCES}

[1]. C. C. Chan, K. T. Chau, J. Z. Jiang, W. Xia Meiling Zhu, and Ruoju Zhang," Novel Permanent Magnet Motor Drives for Electric Vehicles" IEEE Trans on Industrial Electronics, Vol. 43, No. 2, April 1996

[2]. J.M.D, Murphy and F. G. Turnbull, "Power Electronic Control of AC Motors", Pergamon Press, Oxford, 1988

[3]. G. K. Dubey, "Power Semiconductor Controlled Drives", Prentice Hall, New Jersey, 1989.

[4]. T.1.E.Miller, Brushless Permanent Magnet and Reluctance Motor Drive, Clarendon Press, oxford, 1989. 
[5]. R. Krishnan, Electric Motor Drives: Modeling, Analysis and Control, Pearson Education, New Delhi, 2001.

[6]. B. Singh, "Recent advances in permanent magnet brushless DC motors", Sadhana, Vol. 22, Part 6, pp. 837-853,Dec.1997.

[7]. B.Singh, B.P.Singh and S.K.Dwivedi, "Astate of arton different configurations of permanent magnetbrushless machines",IE(I)Journal- EL,Vol.78,pp.6373,June 2006.

[8]. C.L.Puttaswamy, "Analysis, Design and Control of Permanent magnet Brushless Motors, "PhD. Thesis, IIT Delhi,1996.

[9]. Bhim Singh, S SMurthy and A H N Reddy, "A Micro controller Based Speed Controller for Permanent Magnet Brushless DC Motor", IETE Technical Review, Vol. 17, No.5, pp.299-310, SepOct.,2000.

[10]. CLPutta Swamy, Bhim Singh, BPSingh andSSMurthy, "Experimental Investigations on a Permanent Magnet Brushless DC Motor Fed by a PV Array for a Water Pumping System", ASMEJournal of Solar Energy Engineering, Vol. 122,pp. 129-132, Aug., 2000.

[11]. C C Chan," Electrical engineering", vol.III, Electric vehicles.

[12]. Obervations on Electrical hybrid bus design by Christian Anderson, Department of Industrial Electrical Engineering and Automation, Lund Institute of Technology, Lund University, SWEDEN.

[13]. M. Ehsani, et. al, Emodern Electric Hybrid electric and fuel cell vehice: Fundamentals. Theory and design " CRC Press.

[14]. Hendershot, J.R and T.J.E. Millat, "Design of Brushless Magnet motors", Claredon Press, Oxford 1994.

[15]. T. Teratani, S. Okuma:"Automotive Technology Evolved by Electronic Systems", IEEl Trans. On 1A, Vo1.125,No.1O, pp887-894 (2005).

[16]. Daigo Tokunaga, Katsumi Kesamaru, "Development of Novel PM Motors for Sport Type Electric Motorcycles”, 2005.

[17]. Sang-Hun Lee, Tae-Hyoung Kim, JinWoo Ahn, "Electric Powertrain System for E-Scooter with rear two In-wheeled propulsion motors", 2013 International Conference on Electrical Machines and Systems, Oct. 26-29, 2013, Busan, Korea.

[18]. David G. Dorrell, "A Review of the Methods for Improving the Efficiency of Drive Motors to Meet IE4 Efficiency Standards", Journal of Power Electronics,
Vol. 14, No. 5, pp. 842-851, September 2014

[19]. Adrian Ortega Dulanto, "Design of a Synchronous Reluctance Motor Assisted with Permanent Magnets for Pump Applications:, SWEDEN 2015

[20]. Mr. Vidyadhar Gulhane, Prof. M. R. Tarambale, Prof.Dr Y P Nerkar, "A Scope for the Research and Development Activities on Electric Vehicle Technology in Pune City”, IEEE Trans, mag 2006

[21]. Vinatha U, Swetha Pola, "Simulation of Four Quadrants Operation \& Speed Control of BLDC Motor on MATLAB / SIMULINK" TECON 2008-2008 IEEE region 10 conference.

[22]. P Pillay and R Krishnan, "Modeling, simulation, and analysis of permanent Magnet motor drives. Part II: The brushless dc motordrive," IEEE Transactions on Industry Applications, vol.IA- 25,no.2,pp.274-279, Mar./Apr. 1989.

[23]. T. Kenjo, "Permanent magnet and brushless dc motors "first edn, Oxford 1985.

[24]. Sneha K.Awaze, "Four Quadrant Operation Of BLDC Motor In MATLAB/SIMULINK.", 2013 5th International Conference on Computational Intelligence and Communication Networks.

[25]. Khaligh A, Li Zhihao. Battery, ultracapacitor, fuel cell, and hybrid energy storage systems for electric, hybrid electric, fuel cell, and plug-in hybrid electric vehicles: state of the art. IEEE Transactions on Vehicular Technology 2010;59(6):2806-14.

[26]. Whittingham MS. History, evolution, and future status of energy storage. Proceedings of the IEEE 2012; vol. 100(no. Special Centennial Issue):151834

[27]. Lukic S. Charging ahead. IEEE Industrial Electronics Magazine 2008;2 (4):22-31.

[28]. D. C. Hanselman, "Brushless Permanent Magnet Motor Design”, McGraw hill, New York, 1994.

[29]. Alexander Rowe, Gourab Sen Gupta, Serge Demidenko, "Instrumentation and Control of a High Power BLDC Motor for Small Vehicle Applications", 978-1-45771772-7, IEEE, 2012

[30]. Lalit Kumar, Shailendra Jain, "Electric propulsion system for electric vehicular technology: A review", Renewable and 
Sustainable Energy Reviews 29 (2014) 924-940

[31]. Zhu ZQ, Howe D. Electrical machines and drives for electric, hybrid, and fuel cell vehicles. Proceedings of the IEEE 2007;95(4):746-65.

[32]. Hamid A. Toliyat, Tilak Gopalarathnam,"AC machines controlled as DC machines", CRC Press LLC, 2002.

[33]. Manuele Bertoluzzo, Giuseppe Buja, Ritesh Kumar Keshri, Roberto Menis," Analytical Study of Torque vs. Speed Characteristics of PM Brushless DC Drives", IEEE, 978-1-4673-2421-2/12, pp 1618-1689, 2012

[34]. Kavita Jain, "Implementation DSP based Digital Speed controller for Permanent Magnet Brushless DC Motor", M.Tech.Thesis,IITDelhi,1999

[35]. A.Kiruthika, A.Albert Rajan, P.Rajalakshmi,"Mathematical modeling and Speed control of a Sensored Brushless DC motor using Intelligent", IEEE Trans on International Conference on Emerging Trends in Computing, Communication and Nanotechnology (ICECCN 2013), page 211-21., 2011.

[36]. Anand Sathyan, Nikola Milivojevic, Young Joo Lee, Mahesh Krishnamurthy, Ali Emadi," An FPGA Based Novel Digital PWM Control Scheme for BLDC Motor Drives", IEEE transactions o Industrial Electronics, Vol. 56, No. 8, page 3040-3049, August 2009.

[37]. Viliam Fedak, TiborBalogh and Pavel Zaskalick, "Dynamic Simulation of Electrical Machines andDriveSystems UsingMATLABGUI", A fundamental tool for scientific computing and Engg application, vol 1, 2012 [38] N. Ravi, S. Ekram, and D. Mahajan,"Design and Development of a In-Wheel Brushless D.C. Motor Drive for an Electric Scooter", IEEE Trans, mag, 2006

[38]. Alireza Khaligh and Zhihao Li," Battery, Ultracapacitor, Fuel Cell, and Hybrid Energy Storage Systems for Electric, Hybrid Electric, Fuel Cell, and Plug-In Hybrid Electric Vehicles: State of the Art “,IEEE Trans on Vehicular Technology, Vol. 59, No. 6, July 2010

[39]. Liqing Sun; Chan, RuchuanLiang, C.C.Wang, Qingcai. State-of-art of energy system for new energy vehicles. In: IEEE vehicle power and propulsion conference, 3-5 September 2008. VPPC '08, p. 1-8.

[40]. Khaligh A, Li Zhihao. Battery, ultra capacitor, fuel cell, and hybrid energy storage systems for electric, hybrid electric, fuel cell, and plug-in hybrid electric vehicles: state of the art. IEEE Transactions on Vehicular Technology 2010;59(6):2806-14..

[41]. O. Caumont, P. Le Moigne, C. Rombaut, $\mathrm{X}$. Muneret, and P. Lenain, "Energy gauge for lead-acid batteries in electric vehicles," IEEE Trans. Energy Convers., vol. 15, no. 3, pp. 354-360, Sep. 2000.

[42]. Mock Peter, Stephan A. Schmid fuel cells for automotive powertrains - atechnoeconomic assessment. Journal of Power Sources 2009;190(1): 133-40.

[43]. Bauman J, Kazerani M. A comparative study of fuel-cell-battery, fuel-cell-ultra capacitor, and fuel-cell-battery-ultra capacitor vehicles. IEEE Transactions on Vehicular Technology 2008;57(2):760-9.

[44]. Riezenman MJ. Fuel cells for the long haul, batteries for the spurts [electric vehicles]. IEEE Spectrum 2001;38(1):957.

[45]. Hebner R, Beno J, Walls A. Flywheel batteries come around again. IEEE Spectrum 2002;39(4):46-51

[46]. Briat O, Vinassa JM, Lajnef W, Azzopardi S, Woirgard E. Principle, design and experimental validation of a flywheelbattery hybrid source for heavy-duty electric vehicles. IET Electric Power Applications 2007;1(5):665-74.

[47]. Lustenader EL, Guess RH, Richter E, Turnbull FG. Development of a hybrid flywheel/battery drive system for electric vehicle applications. IEEE Transactions on Vehicular Technology 1977;26(2):135-43.

[48]. Miller JM, Bohn T, Dougherty TJ, Deshpande U. Why hybridization of energy storage is essential for future hybrid, plug-in, and battery electric vehicles. In: Proc. IEEE Energy Convers. Congr. Expo. (ECCE), San Jose, CA, 2009, p. 2614-20.

[49]. Khaligh A, Li Zhihao. Battery, ultracapacitor, fuel cell, and hybrid energy storage systems for electric, hybrid electric, fuel cell, and plug-in hybrid electric vehicles: state of the art. IEEE Transactions on Vehicular Technology 2010;59(6):2806-14. 